\title{
Ways and Whys of Summer
}

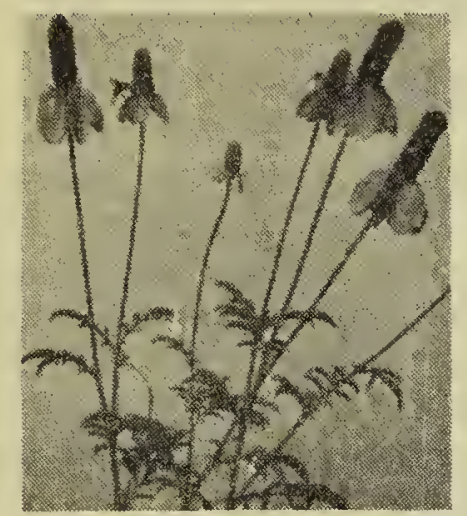

Photo by Carmichael

$\mathbf{F}$ IELDS OF GOLD, ditches spilling over with gold - everywhere evidence of the "fulfilment of the year's desire," as we drove one day in mid-August to the Valley. A field of flax, like a patch dropped from the wide dome of heaven, made us catch our breath-"blue and gold on the plains of God." Very soon tawny stubble would replace the grain. We found ourselves in that mood when "pleasant thoughts bring sad thoughts to the mind." We passed through the shadow of the thought of winter, however, to enjoy this golden day.

We reminisced as we drove along, of the happiness and interest this summer had already given.

In our evening walks on the prairie, Fogarty and I try to miss nothing this "slice of earth" has to offer. Broom rape was very common this early summer. We wonder if all parasitic plants feel cold and clammy to the touch as it does.

One night I stopped to admire Cone-flowers in an arrangement to iire the imagination. Snowberry bushes for a back drop, asters, purple and white, with Gum-weed for colourful side drops-a stage set for comedy or tragedy. A mass of the Cone-flowers, with their high cones and bright yellow ray florets reflexed, like dancing skirts, formed the chorus, while three held front stage. Pale hollow seed cases of flax, like tiny clustered bells, swung in the breeze beside them. Across the field Fogey in confusion was jumping stiffly in all directions. We had seen many little frogs earlier (and wondered why) but they were not frogs he was chasing, but mice. Not Burns "Wee, sleekit, cowrin, tim'rous beasties" but high-jumping fearless little fellows, equipped, it

\section{By Elizabeth Cruickshank}

seemed, with invisible wings. We hurried away but returned with a young Meadowlark found dead in our path. We lifted it, disturbing busy Carrion Beetles, to bury the soft little bundle of feathers on the imaginary stage. The flax bells might toll now for a real tragedy.

On the hottest day this summer we saw Giant Hyssop growing by a valley road. A little lane through the trees, the fresh aromatic scent of mint led us o explore the cool retreat. We were thrilled to find Yellow Wood-sorrel, with its sensitive clover-like leaves that close up at night, beautiful Fringed Loosestrife, Skull Cap, Mint and Burmarigold, with its heavy russet flower heads and magenta coloured stems.

It was the kind of day for gathering petals for our pot pourri jars. Judy knew where the roses formed a red carpet, which she had named "Flowerland", a red carpet on the hillside. What happy memories on dull winter days their fragrance will revive.

But we had this sunny day still to enjoy. Resides a quiet trail we found silver-stemmed white (and pink) Evening Primrose and creamy plumes of Meadow-sweet. This aristccrat of the rose family ' with its smooth mahogany coloured stems, we had not found near Regina before. Bees crowded every blossom. Near a slough vivid pink racemes of Persicaria, white blossomed Arrow-head -a beautiful sight. Owl's clover seemed abundant on the hill top where we found a sloughed snake skin, three feet long. Taverner says Crested Fly-catchers weave cast snake skins into their nests. Again we wonder why.

Swallows crowded the fence wires beside flocks on the road side. The soft wind was full of summer scents. There was music in the air-music that had reached, and passed, its crescendo passage.

Something in the mellowness of the late sunlight saddened us as we neared home. But our spirit rose again ... two young robins were splashing in cur bird bath.

Summer was not yet spent. 